\title{
ANALYSIS OF FISHING TOOLS BUSINESS ON GT-BOATS AS THE ALTERNATIVE OF CANTRANG IN PPP BAJOMULYO, PATI REGENCY OF INDONESIA
}

\author{
Wibowo Tri Wahyu*, Wijaya Suradi, Boesono Herry \\ Master's Program in Coastal Resource Management, University of Diponegoro, Indonesia \\ ${ }^{*}$ E-mail: wahyumayla@yahoo.com
}

\begin{abstract}
The cantrang boat with a size above 30 GT in Juwana Pati District has replaced fishing gear to gillnet, purse seine and bottom longline. The fleets of ships that have switched these fishing gears get permission and carry out fishing operations in the Banda Sea (WPP 718). The problem faced by some fishermen and ship owners who have not switched now is that they still have the body to switch from cantrang to several other fishing gears. See the conditions above, so it is necessary to review further the aspects of business feasibility. The purpose of this study was to determine the income and analyze the value of NPV, the value of B / C Ratio, IRR (Internal Rate of Return) and payback period (PP) on ships that have switched to gillnet, purse seine and bottom longline. The economic aspect is based on research from the income variable with a value of Rp.6,825,000,000 / year for bottom longline vessels, Rp.3,450,000,000 / year for gillnets vessels and Rp.5,130,000,000 / year for purse seine vessels. The results of the financial analysis of the business of fishing the Ship bottom longline using discounted criterion calculations can be said to be feasible and can be continued because the NPV value is Rp.729,476,021. (NPV = positive), the IRR is $25.88 \%$. $(\mathrm{IRR}>\mathrm{i}), \mathrm{B} / \mathrm{C}$ ratio of 1.21 (> 1), PP for 2 years, 3 months, 18 days, while financial analysis of fishing businesses Ship purse seine can also be said to be feasible and can be continued because the NPV value is Rp. .860,746,527 (NPV = positive), IRR of $30.15 \%$ (IRR> i), B / C ratio of 1.29 (> 1), PP for 2 years, 3 months, 18 days. For the business of catching Gillnets, they suffered losses and were not feasible to continue their business.
\end{abstract}

\section{KEY WORDS}

Business, analysis, fishing, Juwana sub-district.

Indonesia is an archipelago with vast territorial waters reaching 5.8 million $\mathrm{km}^{2}$ or three quarters of Indonesia's territory. With a coastline of $81,000 \mathrm{~km}$, Indonesia has around 7,000 fish species and the potential of marine fish resources reaches 6.52 million tons per year (Damayanti, 2015). The fisheries sector has a strategic role in national development. Natural resources potential is very big since Indonesia is known as the largest maritime country in the world. (Triarso, 2012). Pati Regency is one of the regencies in Central Java that relies on special fisheries sector, specifically capture fisheries as one of the sources of regional income. Pati Regency has a $60 \mathrm{~km}$ coastline length and sea territory reaches $432 \mathrm{~km}^{2}$. The fishing tool used by Central Java fishermen is trawl nets, trawl bags, trawl rings, gill nets, fishing rods and other fishing gear (Kisoworo, 2015).

National marine fisheries produced 23.26 million tons in 2017 (KKP, 2018). Central Java is one of the provinces that contributed to national marine fisheries production. For marine fisheries production in Central Java in 2018, it amounts to $446,197,807$ tons (DKP of Central Java Province, 2018). One of the contributions of Central Java itself is supported by the fishery products from Pati Regency, which is equal to $50,478,991$ tons or $11.33 \%$ (DKP of Central Java Province, 2018). The government through the Ministry of Marine Affairs and Fisheries (KKP) issued Minister of Marine Affairs and Fisheries Regulation No. 2 of 2015 concerning the prohibition on the use of trawl and seine nets made fishing boat owners have to replace their fishing tool. KKP re-measures cantrang boat and divide them into three categories, boat under or $<10 \mathrm{GT}$, between 10 and $30 \mathrm{GT}$, and above or> $30 \mathrm{GT}$.

As for the policy stipulated for boat over $30 \mathrm{GT}$, the KKP provided licensing facilities and relocation of fishing areas to Fisheries Management Areas (WPP) 718. In 2016, several 
cantrang boat with a size above 30 GT in Juwana, Pati Regency had replaced their fishing tool into Bottom Longline, Gill Nets, and Purse Seine. The fleet of boats that have switched into these fishing tools got permission and carried out fishing operations in the Banda Sea (WPP 718). The problem faced by some fishermen and boat owners who have not switched yet is that they still hesitate to switch from cantrang to several other fishing tools. Therefore, a further study of fishing business with replacement fishing tools is needed, by analyzing the economy, namely comparing between the production level or the number of catch (output) and the number of inputs i.e. investment and total costs of the Bottom Longline, Gill Nets and Purse Seine boat to find out which is more efficient between these boats. This research would help PPP Bajomulyo fishermen to compare feasible business to develop. Seeing the above conditions, it is necessary to review the aspects of business feasibility. The purpose of this study was to determine the revenue and analyze the value of NPV (Net Persent Value), B/C Ratio, IRR (Internal Rate of Return) and payback period (PP) on boats that have switched to Bottom Longline, Gill Nets and Purse Seine.

\section{MATERIALS AND METHODS OF RESEARCH}

The method used in this study is a descriptive method based on case study. According to Nasir (2009), a case study is a research method that aims to provide a detailed description of the background, typical traits and characteristics of a case or status of an individual, then it will be made into something general. The sampling method is snowball sampling or snowball samples. According to Umar (2004), this sampling method is a technique for determining samples that are initially small in number, then this sample was asked to choose other respondents to be sampled again, and so on until the number of samples continue to increase. Some considerations in determining respondents, namely fishermen who were used as respondents were cantrang fishermen who had switched fishing tools to Bottom Longline, Gill Nets and Purse Seine > 30 GT in Bajomulyo PPP and operating in WPP 718 (Banda Sea).

The method of data collection uses primary data and secondary data. Primary data is obtained directly from respondents through observation, questionnaire, and direct interviews with fishermen. Direct observation is a means to retrieve data using the eyes without the help of other standard tools for this purpose. Interview is the process of obtaining information for research purposes, face to face conversation between the questioner or the interviewer and the respondent using a tool called the interview guide. Questionnaires are a list of fairly detailed and complete questions (Nasir, 2009). Primary data collected economic aspects which include capital, costs (depreciation, supplies, maintenance, licensing, labor, and distribution), and income.

Secondary data is obtained by evaluating the source, the state of the secondary data, and also the limitations of the data, which is needed to obtain data about the past (Sugiyono, 2009). Secondary data was obtained from Central Java Fisheries Statistics, Fisheries and Marine Services of Central Java Province, Bajomulyo Beach Fisheries Port (PPP) which included data on the number of fishermen, number of fish production, number of business and number of fishing tools; and profile of Pati Regency, the general condition of the study area along with a map of the Pati Regency. The data analysis method used is included in discounted criteria because the economic life of the project is more than 5 years. The indicators used are Net Persent Value (NPV), the value of Benefit Cost Ratio $(B / C)$, Internal Rate of Return (IRR) and Payback Period (PP).

\section{RESULTS AND DISCUSSION}

Capital or business investment acts as the main technique for smooth production processes that aim to get maximum profit with minimal costs. Capital can be considered successful if it can provide economic benefits for business owners. The capital needed in a fishing business is a boat, and a boat's engine. 
Table 1 - Average investment capital for fishing business of Bottom Longline, Gill Nets and Purse Seine

\begin{tabular}{ccccc}
\hline \multirow{2}{*}{ No } & Component & \multicolumn{3}{c}{ Cost per Type of Fishing Business (Rp) } \\
\cline { 2 - 5 } & Bottom Longline & Gill Nets & Purse Seine \\
\hline 1 & Boat & $1,300,000,000$ & $1,000,000,000$ & $1,100,000,000$ \\
2 & Catching tool & $550,000,000$ & $700,000,000$ & $400,000,000$ \\
3 & Cooler Machine & $900,000,000$ & $1,000,000,000$ & $800,000,000$ \\
4 & Boat Machine & $520,000,000$ & $450,000,000$ & $400,000,000$ \\
5 & Navigation Tool & $180,000,000$ & $80,000.000$ & $250,000,000$ \\
\hline & Total & $3,450,000,000$ & $3,230,000,000$ & $2,950,000,000$ \\
\hline
\end{tabular}

According to the table above, the investment capital needed are boats, fishing tools, cooler machines, boat engines and navigation tools. The biggest investment capital among these is bottom line with a total investment of Rp3,450,000,000. Details of the capital cost component to buy a boat is Rp1,300,000,000 with an economic life of 15 years. The investment capital to purchase fishing tools is Rp550,000,000; while to purchase a cooler machine is Rp900,000,000 and to purchase boat's machine is Rp520,000,000 and Rp180,000,000 for navigation tool.

The production costs used in this study are divided into two, namely fixed costs and variable costs. Fixed costs consist of maintenance costs (boats, fishing tools, cooler machines, boat's engines, lights and navigation equipment), depreciation, licensing, PHP and profit sharing. Fixed costs must be calculated by business owners to carry out their business. Fixed costs consist of maintenance costs, depreciation costs, and licensing fees. Fixed costs obtained from the results of research on Bottom Longline, Gill Nets and Purse Seine boats in PPP Bajomulyo Juwana is that the boat's economic life is 20 years, the engine's economic life is 5 years and the fishing tools economic life is 5 years. Depreciation costs represent the loss of fixed assets because they are used in the production process. Fixed assets are durable production factors that do not run out in one production process but will gradually run out after several production processes. From the results of the study it is known that the economic life of Bottom Longline, Gill Nets and Purse Seine boats in PPP Bajomulyo Juwana is 20 years, the machine is 5 years and the fishing tools is 5 years.

Table 2 - Details of average fixed costs per year for Bottom Longline, Gill Nets and Purse Seine

\begin{tabular}{ccccc}
\hline \multirow{2}{*}{ No } & \multirow{2}{*}{ Component } & \multicolumn{2}{c}{ Cost per Boat Business Type (Rp) } \\
\cline { 3 - 5 } & & Bottom Longline & Gill Nets & Purse Seine \\
\hline 1 & Boat Maintenance & $61,200,000$ & $86,000,000$ & $69,800,000$ \\
2 & Fishing Tools Maintenance & $12,600,000$ & $35,000,000$ & $27,200,000$ \\
3 & Cooler Machine Maintenance & $28,800,000$ & $50,000,000$ & $24,400,000$ \\
4 & Boat's machine Maintenance & $18,720,000$ & $27,000,000$ & $17,200,000$ \\
5 & Lamp and Navigation Tools Maintenance & $2,880,000$ & $9,000,000$ & $10,500,000$ \\
6 & Depreciation & $359,000,000$ & $323,000,000$ & $298,000,000$ \\
7 & License & $6,175,000$ & $7,000,000$ & $3,150,000$ \\
8 & PHP & $682,500,000$ & $500,000,000$ & $450,000,000$ \\
9 & Profit Sharing & $2,730,000,000$ & $1,380,000,000$ & $2,052,000,000$ \\
\hline & Total & $3,901,875,000$ & $2,417,000,000$ & $2,952,250,000$ \\
\hline
\end{tabular}

Based on table 2, it was found that the fixed costs of fishing business for Bottom Longline boats were Rp3,901,875,000/year, while the fixed costs of fishing business on Gill Nets are Rp2,417,000,000/year. Furthermore, the fixed cost of fishing business on Purse Seine boats is Rp2,952,250,000/year. Maintenance costs are fixed costs incurred by the production agent to repair the investment goods to reduce the severe damage to the investment goods. Non-fixed costs are incurred by business actors which numbers for each trip and year vary. Non-fixed costs are influenced by the amount of production. Non-fixed costs include fuel, lubricant, rations, freshwater, etc. The total variable cost on a Bottom Longline boat is Rp1,446,060,000 per year. Furthermore, the total variable costs on Gill Nets are $\mathrm{Rp} 1,080,060,000$ per year and variable cost on Purse Seine boats is Rp828,360,000 per year. 
Table 3 - Details of the average non-fixed costs per year for the Bottom Longline, Gill Nets and Purse Seine fishing business

\begin{tabular}{ccccc}
\hline \multirow{2}{*}{ No } & Component & \multicolumn{3}{c}{ Cost per Boat Business Type (Rp) } \\
\cline { 3 - 5 } & Fuel & Bottom Longline & Gill Nets & Purse Seine \\
\hline 1 & Oil & $916,000,000$ & $870,000,000$ & $633,600,000$ \\
2 & $24,800,000$ & $38,800,000$ & $36,000,000$ \\
3 & Ration & $130,000,000$ & $160,000,000$ & $147,500,000$ \\
4 & Freshwater & $15,260,000$ & $21,260,000$ & $11,260,000$ \\
5 & Bait & $360,000,000$ & - & - \\
\hline & Total & $1,446,060,000$ & $1,090,060,000$ & $828,360,000$ \\
\hline
\end{tabular}

Table 4 - Average total costs per year for Bottom Longline, Gill Nets and Purse Seine fishing tools

\begin{tabular}{cccc}
\hline \multirow{2}{*}{ Description of Total Costs } & \multicolumn{3}{c}{ Average Total Cost Per Year (Rp/Year) } \\
\cline { 2 - 4 } & Bottom Longline & Gill Nets & Purse Seine \\
\hline Total Fixed Cost & $3,901,875,000$ & $2,417,000,000$ & $2,952,250,000$ \\
Total Non-fixed Cost & $1,446,060,000$ & $1,090,060,000$ & $828,360,000$ \\
\hline Total & $5,347,935,000$ & $3,507,060,000$ & 3.780 .610 .000 \\
\hline
\end{tabular}

The total fixed and non-fixed costs for the Bottom Longline are Rp5,347,935,000 per year. Furthermore, the Gill Nets is Rp3,344,942,000 per year and the Purse Seine is Rp3,780,610,000 per year.

Income obtained from the sales of fish production which is influenced by the size of the fish caught when landed. Income is derived from every kilogram of fish captured multiplied by the average price of each type of fish per kilogram. The amount of income is influenced by the productivity of fishing tools, seasons, and fluctuations in fish prices.

Table 5 - Average Operating Income for Fishing Business using Bottom Longline, Gill Nets and Purse Seine

\begin{tabular}{cccc}
\hline \multirow{2}{*}{ Fishing Season } & \multicolumn{3}{c}{ Income (Rp/year) } \\
\cline { 2 - 4 } & Bottom Longline & Gill Nets & Purse Seine \\
\hline Min & $6,100,000,000$ & $2,400,000,000$ & $1,630,000,000$ \\
Max & $7,550,000,000$ & $4,500,000,000$ & $3,500,000,000$ \\
\hline Average/Year & $6,825,000,000$ & $3,450,000,000$ & $5,130,000,000$ \\
\hline
\end{tabular}

Based on the table above, it can be seen that the Bottom Longline fishing income is around Rp6,100,000,000 - Rp7,550,000,000 per year, with an average income of Rp6,825,000,000 per year, with the average yield per trip Rp1,137,500,000. For the Gill Nets is around Rp2,400,000,000-Rp4,500,000,000 per year, with an average income of Rp3,450,000,000 per year, with the average yield per trip Rp575,000,000. Whereas Purse Seine boats are in the range of $R p 1,630,000,000$ - Rp3,500,000,000 per year, with an average income of Rp5,130,000,000 per year, with the average trip per year Rp855,000,000.

Table 6 - Profit for Bottom Longline, Gill Nets and Purse Seine fishing boat

\begin{tabular}{cccc}
\hline Description & \multicolumn{3}{c}{ Value (Rp) } \\
\cline { 2 - 4 } & Bottom Longline & Gill Nets & Purse Seine \\
\hline Income & $6,825,000.000$ & $3,450,000.000$ & $5,130,000,000$ \\
Total Cost & $5,347,935.000$ & $3,507,060.000$ & $3,780,610,000$ \\
\hline Profit/Loss per Year & $1,477,065.000$ & $-57,060,000$ & $1,349,390,000$ \\
\hline
\end{tabular}

Based on the table above, it can be seen that the fishing business of Bottom Longline makes a profit of Rp1,477,065,000 per year and Purse Seine has a profit of Rp1,349,390,000. However, the fishing business using Gill Nets suffered a loss of Rp. $57,060,000$.

This calculation of financial analysis uses an interest rate of $14 \%$ according to the current average bank interest rate, inflation of $2.57 \%$ of the three fishing businesses using Bottom Longline, Gill Nets and Purse Seine. 
The NPV value of the Bottom Longline boat is Rp729,476,021. Whereas the Purse Seine is Rp860,746,527. Both have a positive NPV value and this indicates that the fishing business of Bottom Longline and Purse Seine is worth to continue. For Gill Nets fishing, it has a negative value of -Rp.1.907.451.501 so that Gill Nets is considered not feasible. The higher the Net Present Value (NPV) of a business, the better the business and business that can increase profits will have bigger Net Present Value (NPV). According to Umar (2003), NPV is the difference between the Present Value of investment and the current value of net cash receipts (operational cash flows and terminal cash flows) in the future. The NPV is also the difference between the investment market value and the costs incurred. Discounted cash flow valuation is the process of evaluating investments through a cash flow discount rate in the future. The feasibility of a business can be seen from the results of NPV calculations. If the NPV value is positive then the investment is feasible, otherwise, if negative, the investment will be rejected or not feasible and if the value of NPV $=0$ then the business can be feasible.

Table 7 - NPV for fishing business of Bottom Longline, Gill Nets and Purse Seine

\begin{tabular}{ccc}
\hline No. & Business Type & NPV Value (Rp) \\
\hline 1 & Bottom Longline & $729,476,021$ \\
2 & Gill Nets & $-1,907,451,501$ \\
3 & Purse Seine & $860,746,527$ \\
\hline
\end{tabular}

The IRR value on the Bottom Longline boat is $25.88 \%$, while the Purse Seine is $30.15 \%$. This means that the business is able to provide a profit rate of $30.15 \%$ per year from all investments invested during the 5-year fishing period. Fishing business Bottom Longline and Purse Seine have a value that exceeds the discount factor value which is worth $14 \%$ so, it can be said that it's worth continuing. As for Gill Nets fishing businesses, it has a negative value of $-23.51 \%$ so the business can be considered not feasible. According to Umar (2003), if the IRR value of the discount rate value means it is feasible, if the IRR < from the discount rate then the business is not feasible, and if the IRR = discount rate means it is in BEP.

Table 8 - IRR value for fishing business of Bottom Longline, Gill Nets and Purse Seine

\begin{tabular}{ccc}
\hline No. & Business Type & IRR Value (\%) \\
\hline 1 & Bottom Longline & 25.88 \\
2 & Gill Nets & -23.51 \\
3 & Purse Seine & 30.15 \\
\hline
\end{tabular}

The $B / C$ ratio of the Bottom Longline boat obtained from the above data is 1.21 . This means that every rupiah spent will result in the income of 1 rupiah 21 cents. Whereas in the Purse Seine, the value is 1.29 , which means that every rupiah of the costs incurred will gain an income of 1.29 cents. On the results of the study, the value of $B / C$ is greater because the income obtained per year is also greater. It can be seen that the $B / C$ ratio in the Bottom Longline and Purse Seine fishing business more than 1 therefore it means that the business is feasible to run and can be continued. The $B / C$ ratio is assessed by comparing the benefits and costs within 5 years. For Gill Nets fishing business, it has a value below 1 , which is 0.41 so that the business cannot be considered feasible. If the $B / C$ ratio is more than one, then the business is feasible and can be continued, if the $B / C$ ratio is equal to one then the business is at break-even point and if the $B / C$ ratio is less than one then the business is not feasible and cannot be continued.

Table $9-\mathrm{B} / \mathrm{C}$ value for Bottom Longline, Gill Nets and Purse Seine fishing business

\begin{tabular}{ccc}
\hline No. & Business Type & B/C Value \\
\hline 1 & Bottom Longline & 1.21 \\
2 & Gill Nets & 0.41 \\
3 & Purse Seine & 1.29 \\
\hline
\end{tabular}


Table $10-\mathrm{B} / \mathrm{C}$ value on Bottom Longline, Gill Nets and Purse Seine fishing business

\begin{tabular}{ccc}
\hline No. & Business Type & PP Value (Year) \\
\hline 1 & Bottom Longline & 2.50 \\
2 & Gill Nets & 6.50 \\
3 & Purse Seine & 2.30 \\
\hline
\end{tabular}

The Pay Back Period (PP) value of the Bottom Longline fishing business obtained from the above data for 2 years 6 months 0 days. While in the Purse Seine business for 2 years 3 months 18 days. If the value of PP is less than 3 years, it means that the rate of return on the Bottom Longline boats can be considered fast. The period is used to recoup investment expenses (initial cash investment) using cash flow. In other words, the Payback Period is the ratio between the initial cash investment and the cash inflow which results are units of time. According to Ernaningsih (2008), Payback Period is the rate of return on capital or the length of time used to cover up the original investment costs. The faster the return on investment in a business, the better the business pattern because the capital flows more smoothly. The return period is usually expressed in per year span.

\section{CONCLUSION}

Economic aspects based on research from income variables with a value of Rp6,825,000,000/year for Bottom Longline boats, Rp3,450,000,000/year for Gill Nets boats and Rp5,130,000,000/year for Purse Seine boats.

The results of the financial analysis of Bottom Longline fishing business using discounted criterion calculations can be considered feasible and can be continued because the NPV value is $R p 729,476,021$. (NPV = positive), the IRR is $25.88 \%$. (IRR> $\mathrm{i}$ ), B/C ratio 1.21 ( $>1$ ), PP for 2 years, 3 months, 18 days, while financial analysis of Purse Seine fishing businesses can also be said to be feasible and can be continued because the NPV value is Rp860,746,527 (NPV = positive), IRR of $30.15 \%$ (IRR> i), B/C ratio of 1.29 (> 1), PP for 2 years, 3 months, 18 days. For the Gill Nets, they suffered losses and considered not feasible to continue their business.

\section{REFERENCES}

1. Damayanti. 2015. Analisis Daya Saing and Efek Divergensi Usaha Perikanan Jaring Cumi di Kecamatan Juwana. National Seminar Paper, Seminar Nasional Universitas PGRI Yogyakarta, pp. 559-565.

2. Dinas Kelautan and Perikanan Kabupaten Pati. 2018. Data Statistik Tangkap Kabupaten Pati.

3. Dinas Kelautan and Perikanan Provinsi Jateng. 2018. Produksi Perikanan Tangkap Jawa Tengah.

4. Ernaningsih, D. 2008. Analisis Usaha Penangkapan Ikan Teri Dengan Bagan Perahu di Teluk Jakarta. J. Imiah Satya Negara Indonesia, 1(2): 22-26.

5. Kisoworo. 2015. Analisis Hasil Tangkapan, Produktivitas, and Kelayakan Usaha Perikanan Rawai Dasar di PPI Bajomulyo I Kabupaten Pati. Journal of Management Aquatic Resources, Vol 2. No 3. Pp. 190-196.

6. Nasir, M. 2009. Metode Penelitian. Jakarta: Ghalia Indonesia.

7. Pelabuhan Perikanan Pantai Bajomulyo. 2014. Data PPP Bajomulyo 2018. Pati.

8. Umar, H. 2003. Studi Kelayakan dalam Bisnis Jasa. Jakarta: PT. Gramedia Pustaka Utama.

9. Singarimbun, M. \& Effendi, S. 2006. Metode Penelitian Survei. Jakarta: LP3ES.

10. Sugiyono. 2009. Metode Penelitian Kuantitatif, Kualitatif, and R\&D ( $8^{\text {th }}$ Edition). Bandung: Alfabeta.

11. Triarso. 2012. Potensi and Peluang Pengembangan Usaha Perikanan Tangkap di Pantura Jawa Tengah. Jurnal Saintek Perikanan, Vol. 8. No. 1, pp. $65-73$. 